\title{
Creative Thinking in Interior Architecture Education: Basic Design Courses
}

\author{
Gülsüm Damla Aşkın ${ }^{1 *}$ \\ ${ }^{1}$ Mimar Sinan Fine Arts University, Department of Interior Architecture, Istanbul 34427, Turkey
}

\begin{abstract}
Basic Design courses aim to enable the students to produce creative designs with original and aesthetic perspectives in Interior Architecture Education in Turkey. In this study, it was aimed to develop the skill to use creative thinking of the students studying Interior Architecture and to bring the childish creativity back in the Basic Design course. Firstly, the Interior Architecture students were made to prepare an individual preliminary design work within the workshop carried out for this purpose. One week after the individual work, a workshop was held together with the kindergarten students. The aim of the workshops held in the scope of Basic Design course is to make the students generate ideas more quickly, be aware of the new design methods, and to gain the skill of working with individuals from various age groups in harmony. A survey was carried out with the participation of 16 academicians in the field of Interior Architecture and the designs obtained in the beginning and end of the study were evaluated by comparing them in terms of the use of creative thinking. To conclude, it can be said that the interior architecture students used creative thinking more effectively together with kindergarten students.
\end{abstract}

Keywords: Interior architecture, education, basic design, creative thinking

\section{Introduction}

The first stage of the design education constitutes Basic Design courses in Interior Architecture education in Turkey. Basic Design courses aim to enable the students to produce creative designs with original and aesthetic perspectives that meet the requirements of the current social, cultural, and technological developments. In this respect, the Basic Design course plays an important role in the development of the creativity.

The freshmen of the Interior Architecture begin design education after getting training to improve their behaviour in the secondary and high school. The students are involved in the mental learning and teaching process together with the primary school period. The mental processes play an active role in each stage of the basic design course. The fact that the students had an education based on rote-learning from a kindergarten to the university makes it difficult for them to perceive the mental design process [1]. At the age of thirteen, the creativity reaches its peak and it lies fallow by the time unless it is recalled [2]. The

* Corresponding author: damlaaskin@sehir.edu.tr 
creativity is formed by what the individual learns throughout his/her life. However, it is known that the period when the creativity develops the most is the kindergarten period. The self-expression methods of the children who go to kindergarten before compulsory education are more original and creative than adults [3]. The goal of design education, which is given in the first year of the Interior Architecture education, is to recall the creativity that has begun to vanish over time and to develop the skill to use creative thinking of the students.

Within the Basic Design courses in Interior Architecture, the disciplines such as music, literature, graphic design, cinema, plays, performance arts, visual and digital arts are used to improve creative thinking. In this study, it is aimed to recall the creative thinking skill gained in the past by working together with the kindergarten students. Accordingly, it is aimed to transform the free drawings of the children going to kindergarten into the design and to enable the Interior Architecture students to use creative thinking effectively.

The purpose of this research is to provide interior design students with new methods to improve their ability to interpret other disciplines that require creativity, to use childish creative thinking effectively, and to work in harmony with the various age groups. Therefore, the qualitative data analysis was carried out by examining the current Basic Design education and its methods at first. Within the scope of the research, a workshop was held with the freshmen of Interior Architecture who took Basic Design course at Işık University in the fall semester in 2017-2018. The interior architecture students and the theme of the work were considered as constants, and the working method was considered as a variable. In the study, upper year students taking project course were excluded. At the first stage of the study, the students were asked to design a one-story playhouse in the activity area in Ayazağa Işı k Kindergarten in. According to the kindergarten manager, playhouse was a significant necessity for school. The 6-year-old children, who study at Işık Kindergarten, were also asked to draw the picture of the playhouse to be constructed in the activity area.

One week after the preliminary work, each Interior Architecture student was asked to repeat the same design process together with a kindergarten student. In the same working environment, the interior architecture students are expected to be inspired by the children's imagination and their drawings. The purpose of the workshop is not to deliver a finished project but to shape the functions and form of the playhouse with the ideas of kindergarten students. After the collaborative work, the Interior Architecture students transformed their design ideas into physical forms as models. In the last stage of the study, the students' works designed with both perspectives were evaluated by 16 Interior Architecture academicians using a survey.

\section{Importance of basic design courses in interior architecture education}

Interior Architecture is a field of occupation that uses scientific and technical data for meeting the requests of the user as well as satisfying functional needs [4]. Interior architecture departments established under architecture, fine arts and design faculties, provide education with influences from different disciplines based on the characteristics of its faculty.

Interior architecture students are expected to interpret all disciplines and develop designs within the integrity of the space [5]. Within this context, it is only possible with basic design courses that students can provide solutions for problems, state their ideas and put them into practice.

In the $21^{\text {st }}$ century, when the knowledge is constantly updated, interior design students must also react to this change, produce new ways of thinking and designs. The Basic 
Design course taken in the first year of interior architecture program lays the professional foundations, affect future project courses [6]. Within this respect, Basic Design courses gain more importance in the interior architecture education.

Purpose of Basic Design courses has been freeing students of conditioning and giving creativity, imagination, personal expression opportunities prominence ever since the school of Bauhaus [7]. Basic Design education is a process that activates intellectual stages of students such as perception, impression, observation, researching, association, invention, knowledge and assessment and transforms such stages into originals forms. The design process consists of knowledge, analysis of knowledge, research, thinking, discussion, sketches leading to creative results, presentation boards, search for the proper material for the study and the final outcome [8].

As the goal of design education is to guide creative individuals with aesthetical perceptions, Interior Architecture education must also be improved so that it supports creativity [9]. Especially in the information and communication age, needs and personal choices become more and more various, and the role of creativity in interior architecture design gets more and more significant. Gropius stated that the purpose of education is teaching a way, method for approaching problems rather than providing a certain information-skill. Considering that the design education is a process of creating, experiencing and researching, methods that support such process and bring creativity forward become more important [10]. A design education is provided in consideration of basic designing principals such as color, ratio, difference, integrity, rhythm, balance, and contrast in order to contribute to visual and intuitive developments of students. Creativity is improved through working, experiencing, observing, the researching and perceiving. Principals adopted in Basic Design courses improve the perceptions and experiences of students and contribute to their creativity.

\section{Basic design courses and creativity}

According to Torance, creativity is researching spaces, disturbing or missing elements and making assumptions, testing them; comparing the results and attaining an outcome [11]. Within this respect, creativity refers to a process that includes innovation and improves with environmental effect.

Thinking, creating new things, assessing objects and situations from different points of view with the help of education is defined as creativity, and it involves curiosity, imagination, invention, and originality [12]. In other words, thinking leading to new ideas is centered around creativity.

Creativity requires developing original designs through benefiting from experiences and new information. Creativity is encountered in first years of life and demonstrated in a child's play for the first time. Children find a chance to express themselves through painting, listening to musing in different activities in kindergartens. Furthermore, as a result of the "Torrance Test of Creative Thinking" [13], it has been determined that creative thinking scores of children receiving preschool education are significantly higher than children not receiving preschool education [14]. Kindergarten period affects the whole life of children when their creativity improves the most. With the primary school period, students get involved with the education system towards behavior correction. And at the age of 13, creativity reaches its peak and lies fallow unless recalled [15]. Purpose of the Basic Design course provided in the first year of Interior Architecture education is to ensure that students produce more original projects by recalling the fading creativity. 


\section{Workshop processes}

Creative design process improves perception, understanding, interpreting and expressing skills of students. Applied education programs, in which students actively participate in courses, are more commonly preferred in Basic Design courses [16]. Within this respect, a workshop has been held between the Işık University Interior Architecture Department students and Işı1k Ayazağa Kindergarten 6-age group students in the 2017-2018 Fall semester within the University. The workshop has been held with the approval and opinions of the principal of Işı Ayazağa Kindergarten.

\subsection{Project area}

Maximum $20 \mathrm{~m}^{2}$ part of the activity hall, of which is approximately $35-40 \mathrm{~m}^{2}$, can be used for creating a playhouse. Determining the location of the house within the hall has been left to the students, there has not been a limitation.

\subsection{Objective}

It has been aimed with the workshop that the creativity of interior architecture students had before the education system towards behavior correction is recalled through designing along with kindergarten students within the same room. The purpose of the workshop has been ensuring that students get knowledge on basic design principals and methods, develop ideas from a two-dimensional, abstract image, and get used to teamwork for exchanging ideas. It has been expected that, following the idea generation stage, skills towards creating a form and conceiving a structure are improved. As a result of the study, it will be ensured that previously existing creativity skills of interior architecture students are recalled while creative thinking skills of kindergarten students are improved.

\subsection{Sample}

The study has been conducted between Interior Architecture junior year students having received the Basic Design course in Işı1k University and the 6-age group students in Işık Kindergarten. In the study, students not having received the Basic Design course or higher year students taking project courses have been left outside the scope of the study.

\subsection{Methodology}

The workshop includes a 3-week process, consisting of personal market production, joint workshop study, and final market study. What is expected in the workshop is not delivery of a completed project, but shaping the functions and form of the playhouse with the ideas of kindergarten students.

\subsubsection{First step}

First year students of Interior Architecture department have been asked to make models of the playhouse to be located in the activity area in Işı Ayazağa Kindergarten. 


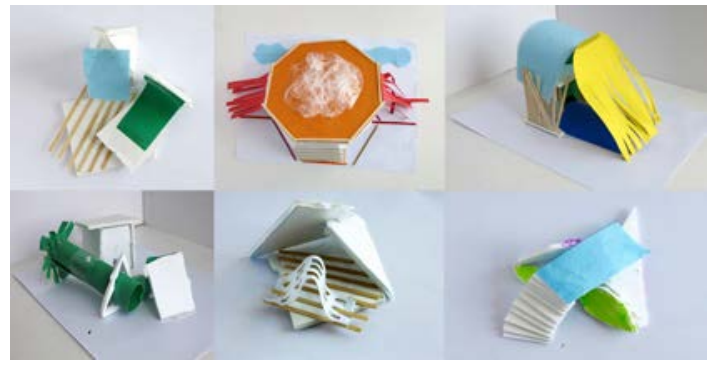

Fig. 1. Basic Design Studies of Interior Architecture Students

\subsubsection{Second step}

6-age group students in Işık Kindergartens have been asked to draw the pictures of the playhouse to be located in the activity area in their school. Kindergarten students take a weekly course in which they make models from discarded materials. Therefore, material and color choices have been left to students' preferences.

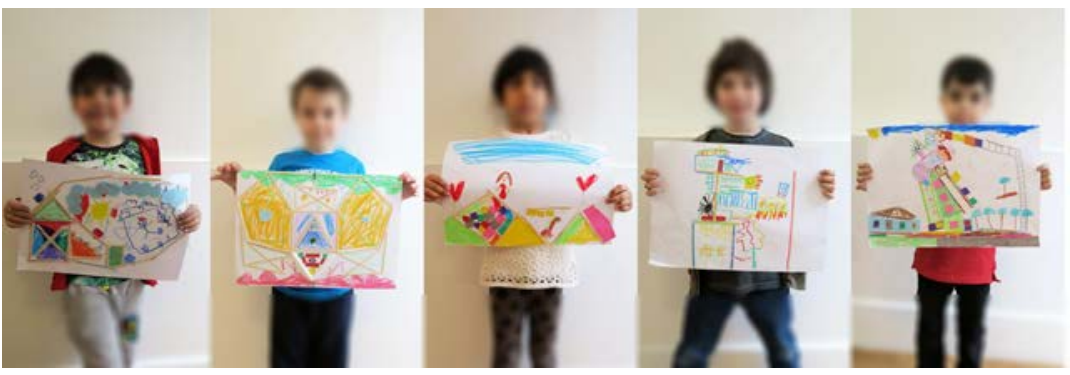

Fig. 2. Design Studies of Kindergarten Students

\subsubsection{Third step}

Interior Architecture students have been paired off with the kindergarten students, thus ensuring that they repeat the same design process together. In this process, ideas of the kindergarten students have been received, and they expressed the playhouse they imagined on their drawings. Afterwards, Interior Architecture students have designed a model with the help of drawings by kindergarten students. During the process, students have had the opportunity to have one-to-one discussions and help each other.

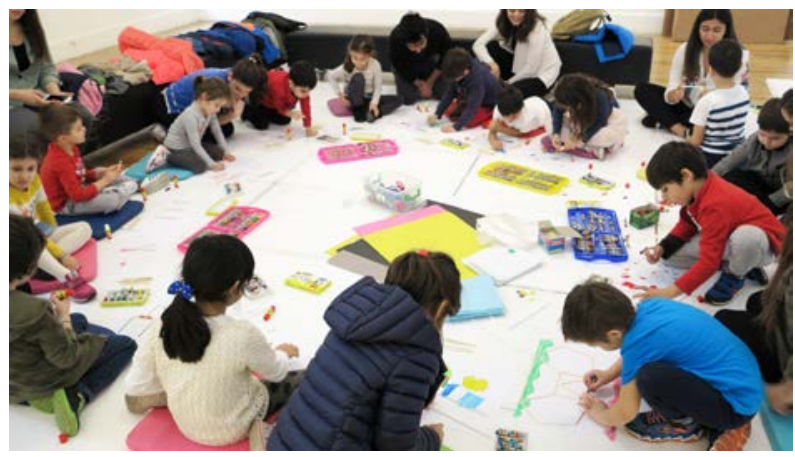

Fig. 3. Students Working Together 

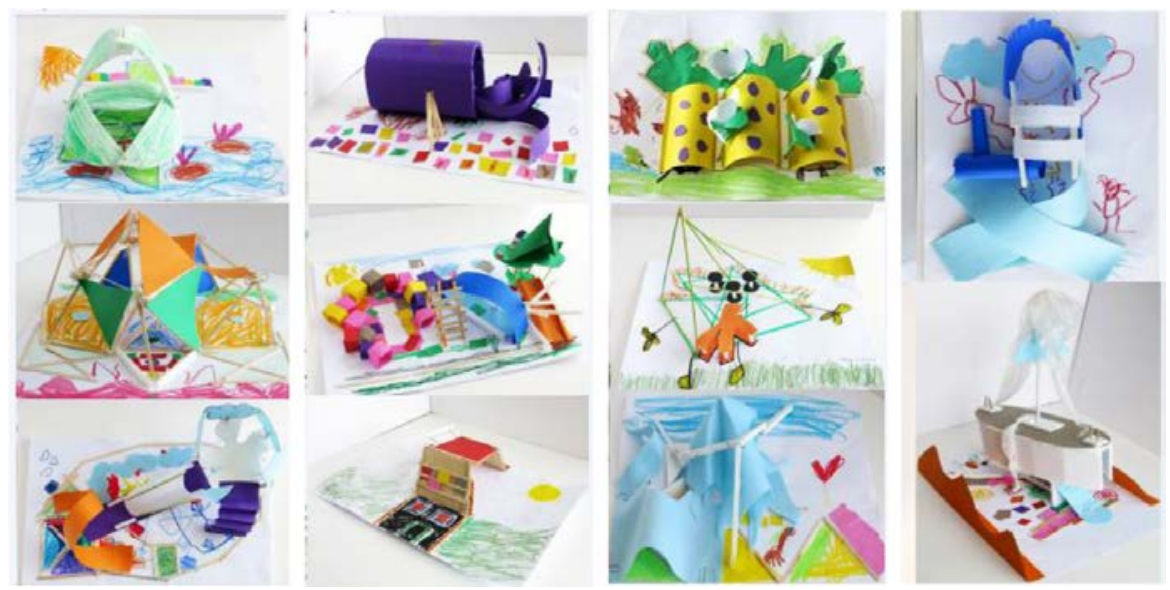

Fig. 4. Design Studies of Interior Architecture Students Together with Kindergarten Students

\subsection{Results}

A survey was carried out with the participation of 16 academicians in the field of Interior Architecture and the designs obtained in the beginning and end of the study were evaluated by comparing them in terms of the originality, use of creative thinking, childish creativity, working in harmony and contribution to basic design courses.

Table 1. Results of Survey

\begin{tabular}{|c|c|c|c|c|c|c|}
\hline \multicolumn{2}{|c|}{ Survey Questions } & Originality & $\begin{array}{c}\text { Use of } \\
\text { Creative }\end{array}$ & $\begin{array}{l}\text { Childish } \\
\text { Creativity }\end{array}$ & $\begin{array}{c}\text { Working in } \\
\text { Harmony }\end{array}$ & $\begin{array}{l}\text { Contribution } \\
\text { to Basic }\end{array}$ \\
\hline \multirow{2}{*}{$\begin{array}{c}\text { Number of } \\
\text { Academic } \\
\text { s } \\
(16)\end{array}$} & $\begin{array}{c}\text { availabl } \\
\mathrm{e}\end{array}$ & 13 & 14 & 14 & 16 & 16 \\
\hline & not & 3 & 2 & 2 & 0 & 0 \\
\hline \multicolumn{2}{|c|}{$\begin{array}{c}\text { Percentage of } \\
\text { Success }\end{array}$} & $81,25 \%$ & $87,50 \%$ & $87,50 \%$ & $100 \%$ & $100 \%$ \\
\hline
\end{tabular}

The result of the survey study revealed that $81.25 \%$ of the academicians making the evaluations stated their opinion that the design works obtained at the end of the workshop were more original than the preliminary works and that the students could use creative thinking more effectively. $87.5 \%$ of the academics think that the Interior Design students could bring out their childish creativity through their designs. The time was recorded during the workshop and it was observed that all of the students decided on their design ideas easier and applied it more quickly by taking advantage of the pictures of the kindergarten students. The Interior Architecture students and the Kindergarten students worked in harmony in the same environment and the students realized that there may have been new design methods.

\section{Conclusion}

Changing environmental conditions, technology and a variety of problems indicate the need for more original and creative solutions. As I mentioned above, students with different pasts, coming from different conditions, try to provide creative solutions for today's 
problems during and after the Interior Architecture education. In Basic Design courses provided in the first year of Interior Architecture education, students acquire the skill to formalize their ideas. Within this sense, it is concluded that Basic Design courses establish a transition stage between secondary education and university.

Within the scope of the study, a case workshop has been conducted in order to ensure that interior architecture students can satisfy needs such as creativity in design, transforming the available knowledge to what is new, providing alternative solutions, questioning and discussing. A playhouse has been designed for the activity area in Ayazağa Işık Kindergarten with two different points of view within the workshop. Contributions have been made to the improvement of creativity skills of both Interior Architecture students and kindergarten students in order to establish an interactive working environment.

As a result of the conducted workshop, Interior Architecture students have had an idea of basic design principles, developed design ideas from two-dimensional drawings, and been involved in teamwork. They have harmoniously created a new form after the idea generation stage. Furthermore, it has been ensured that the creative thinking skills of kindergarten students are improved while the previously existing creative ideas of interior architecture students are recalled.

A survey was carried out with the participation of 16 academicians in the field of Interior Architecture and the designs obtained in the beginning and end of the study were evaluated by comparing them in terms of the use of creative thinking. In this process, attention has been drawn to the necessity of co-working with different age groups and using different disciplines during the study within the scope of Basic Design courses in Interior Architecture education. As a result, it can be said that the Interior Design students can use creative thinking more effectively during the joint workshop, the produced models contribute directly to the Basic Design course and allow the development of new design methods.

\section{References}

1. T. Zorlu, B. Akgül, vs., A Different View of First Year Design Studios in Interior Architecture Education; space from picture; Kandinsky, IÇMEK / 2nd National Congress of Interior Architecture Education, Istanbul, Turkey (2012)

2. E. Aslan, E. Aktan, I. Kamaraj, The Effect of Kindergarten Education on Creativity and Creative Problem-Solving Ability, M.U. Atatürk Education Faculty Journal of Educational Sciences, 9, 37-48 (1997, 2001)

3. M. Yaşar, N. Aral, The Impact of Pre-School Education on Creative Thinking Skills, Educationscience, 3 (2), 201-209 (2010)

4. Ç. B. Gökhan, A. Atasoy, A Model Proposal for Interior Architecture Education Program Design and Development, ITU Journal, 4/2, 25-36 (2005)

5. L. Arıdağ, A. E. Aslan, Design Studies-1 Effect of Creative Drama Activities on the Development of Creative Thinking Skills of Architectural Students, Megaron, 7(1): 4966 (2012)

6. H. T. Örmecioğlu, A. Uçar, First Design Studio Experience in Education of Interior Architecture: an Example of Akdeniz University, Procedia - Social and Behavioral Sciences, 51, 1107 - 1111 ( 2012 )

7. L. Arıdağ, A. E. Aslan, Design Studies-1 Effect of Creative Drama Activities on the Development of Creative Thinking Skills of Architectural Students, Megaron, 7(1): 4966 (2012)

8. İ. San, Arts Education Theories, Utopia Publishing, (2010) 
9. A. Akyıldız, Hatırnaz, Design Suggestion for Developing Creativity in Design Education: Design Cycle, Proficiency in Art Thesis, Mimar Sinan Fine Arts University, Institute of Science, (2010)

10. U. T. Karsl1, S. Özker, The contributions of workshops on formal interior architecture education. Procedia-Social and Behavioral Sciences, 152, 47-52 (2014)

11. E. P. Torrance; E. B. Orlow, Test of Creative Thinking, norms and technical Manual, bensenville Scholastic testing service Inc, (1974)

12. A. Besgen, Teaching/Learning Strategies Through Art: Painting and Basic Design Education, Procedia-Social and Behavioral Sciences, 182, 420-427 (2015)

13. A. E. Aslan, Puccio, G., Developing and Testing A Turkish Version of Torrance Tests of Creative Thinking: A Study of Adults. Journal of Creative Behavior, Massachusetts, 40 (3), 163-178 (2006)

14. D. Onur, T. Zorlu, Training Methods and Creativity Relevant to Design Studios, www. tojdac. org., (2017)

15. M. Yaşar, N. Aral, The Impact of Pre-School Education on Creative Thinking Skills, Educationscience, 3 (2), 201-209 (2010)

16. H. Kilıçaslan, B. E. Ziyrek, A Research About Creativity in Design Education, Procedia - Social and Behavioral Sciences, 46, 1461-1464, (2012) 